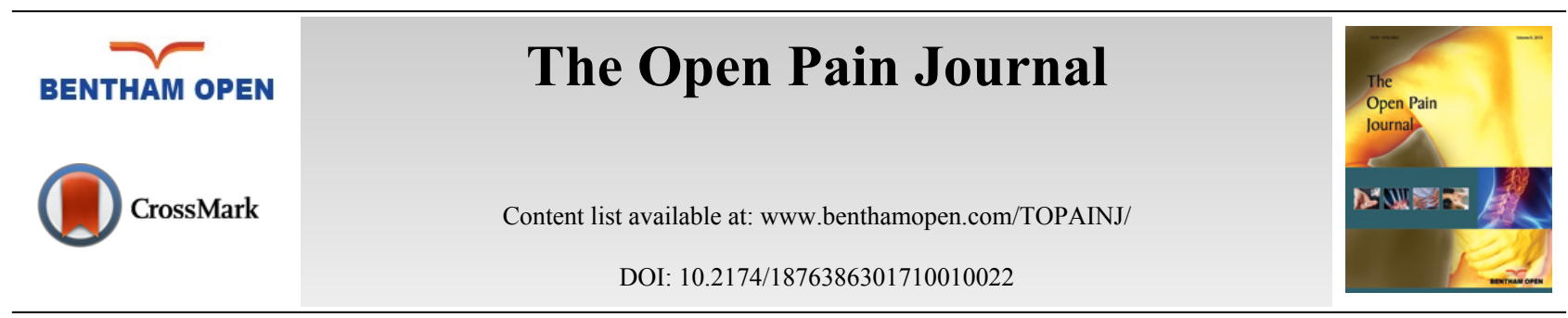

DOI: $10.2174 / 1876386301710010022$

RESEARCH ARTICLE

\title{
When Pain is Beyond Biology - A Case of Fake Leprosy
}

Lazslo Antonio Avila*, Eurides Maria de Oliveira Pozetti, Gislaine Fusco Fares, Rosa Maria Cordeiro Soubhia, Marilia Capuco Oliveira and Andreia Yumi Tomiyasu

Medical School of Sao Jose do Rio Preto, Brazil

Received: December 30, 2016

Revised: May 10, 2017

Accepted: May 17, 2017

\section{Abstract:}

\section{Background:}

Pain is a complex phenomenon that implies pathophysiological processes and psychosocial components. A 56-year-old female patient complaining of pain and presenting with multiple mild physical signs was examined by a multidisciplinary team from the EarNose-Throat, Dermatology, Hematology, General Clinics, and Psychiatry and Psychology Departments.

\section{Objective:}

To present a significant case where pain is primarily caused by psychological conflicts.

\section{Method:}

A multidisciplinary approach, with medical and psychological interventions.

\section{Results:}

The patient was deeply convinced; she had been contaminated by leprosy. Her enrooted personal beliefs, including religion and moral conflicts, seem to be the primary cause for her putative 'disease', a condition that was not confirmed by exhaustive exams.

\section{Conclusion:}

Pain normally is related to several factors, including biological, psychological and cultural. Some complex cases should be investigated by a multidisciplinary team of specialists, in order to identify extra-physiological components.

Keywords: Biopsychosocial, Leprosy, Multidisciplinary, Pain, Psychosocial, Psychology.

\section{INTRODUCTION}

The widely known definition of 'pain' is 'an unpleasant sensory and emotional experience associated with actual or potential tissue damage, or described in terms of such damage" [1]. Besides its scientific foundation covering almost all forms of organic pain of evidenced pathophysiological or central origins, the definition still leaves plenty of room for subjective aspects that suffering people may present.

As stated the famous definition by McCaffery [2]: "Pain is whatever the experiencing person says it is, existing whenever the experiencing person says it does", pain and suffering usually shape a complex and tangled whole. If, on one hand, there is continuous research on all aspects of pain manifested in the most diverse areas of medicine, on the other, pain poses countless questions for doctors and the other health professionals treating the complaints and demands of patients.

Several psychiatric conditions accompany and influence the experience and expression of pain [3 - 8]. These include from the old hypochondria to the many presentations of depression and anxiety, some psychotic conditions and the

\footnotetext{
* Address correspondence to this author at the Av. Anisio Haddad, 8205, Bl. 4, apt 34, Sao Jose do Rio Preto, SP 15091-743, Brazil; Tel:
} 55-17-3232-4905; Fax: 55-17-3227-8133; E-mail: lazslo@terra.com.br 
range of disorders grouped as somatization (somatoform, dissociative, conversion, etc.). Depression, in particular, is intimately connected with painful sensations, both as an antecedent, making 'real' pains be lived much more painfully, and as a consequence of having a nociceptive medical condition. In fact, depression normally accompanies pain from the outset to the outcome.

Many studies have shown the complex interactions between psychosocial and organic factors in pain [9 - 21]. Another point of interest is 'somatosensory amplification', the magnification of any sensation that can make pain an extraordinarily unbearable condition, both in the presence or in the absence of real danger [22 - 24]. The same can be said for the role of 'catastrophizing' related to the patient's experience of pain [25 - 30].

However, there are other complex situations where pain as an individual sensory and emotional experience should be considered, such as the diverse meanings of life, death and disease that any particular person may assume as part of their personality. Herein we will present a case, treated at a university hospital that illustrates how the power of beliefs and emotional conflicts can manifest as the presentation of a complex clinical condition and how a multidisciplinary approach can better understand suffering people.

\section{MATERIAL AND METHODS}

This study was conducted at the university hospital of the State Medical School of Sao Jose do Rio Preto, Brazil. It was not planned as research, but rather as a normal regular clinical attendance of a putative organic disease. The patient was supposedly infected by leprosy. The period of time during which she was followed up was between 2013 until the end of 2016.

The patient was treated in the departments of Ear-Nose-Throat, Dermatology, Haematology, General Clinics, and Psychiatry and Psychology. The current methods of examination of each specialty were adopted. The psychologist adopted the psychodynamic theory and methodology for his investigation. The data collected were analysed by the clinical categories (aetiology, natural history of the disease, evolution and forms of treatment) of each specialty and by a general consensus of the clinical team who treated the patient.

\section{RESULTS AND DISCUSSION}

A 56-year-old female Caucasian patient, who was married with two children, presented with generalized pain and complaining of different bodily symptoms. She was submitted by the different departments to several physical examinations and sets of exams, including two biopsies and an electroneuromyography for a supposed infectious disease. However, no significant results were found and the treatment by the multidisciplinary team was unsuccessful. The patient continues to seek medical attention and her case shows the complexities of the presentation of complaints of pain in somatizing patients.

Leprosy (Hansen Disease) is a chronic infection that has affected humanity for thousands of years. According to the World Health Organization, the most common signs in the diagnosis of leprosy are hypopigmented or erythematous macules with sensory loss. Nerve alterations, generally related to the nose, face and the extremities, can cause pain, paresis and paralysis. Physical weakness and decreased vision may also be present. Although it is now a curable condition, social stigma has always been associated with leprosy.

The patient came for her first medical consultation on December 4th, 2013 with generalized pain, a burning sensation in her nose, very slightly pale skin patches and a feeling of weakness. She was physically examined, and the usual laboratory tests were carried out, but nothing exceptional was found. Even so, she was referred for a biopsy as she had stated that she had been in contact with a patient diagnosed with leprosy, and she believed that she could have been contaminated. Nothing relevant was identified in the exams.

Six days later (10/12/13), she was seen in the Ear-nose-throat (ENT) Outpatients Clinic with a lesion on her left nasal sept, with diffuse pain of the nose, face and larynx. She presented sporadic rhinorrhea, a sensation of a lump in the throat and pain in her chest (retrosternal). In her physical exam, a reddish patch was found on her palate, and she was referred for further investigations. The results were negative.

Two months later (12/2/14), she returned with complaints of worsening of her symptoms and a feeling of disfigurement of her face, nose and mouth. A second biopsy was performed and a diagnosis of unspecific plasma cell stomatitis was reached. 
She was discharged from the ENT Clinic and referred to the Haematology and Dermatology Clinics due to diagnostic hypotheses of multiple myeloma or leprosy.

In her consultation in the Haematology Department (24/2/14), she complained of a black spot in the right eye and generalized body pain. After careful examination and multiple exams, including an investigation of the antinuclear antibodies, the doctors excluded any haematological pathology and she was referred to the General Clinics Department and to an ophthalmologist.

On $5 / 5 / 14$, she was seen in the Ophthalmology Department for a complaint of poor visual acuity. After a thorough evaluation in which minor changes were found, she was prescribed glasses and discharged. During the following consultations in the Dermatology Service, she continued with the complaint linked to putative leprosy, but did not use the glasses due to pain in the nasal region.

On June 3/6/14, a general clinician skilled in complex cases saw her. She was presenting with intermittent paresis of the upper and lower limbs, sleep problems and a severe loss of weight. After a detailed exam and anamnesis, the physician asked the patient to talk about other possible factors related to her physical condition. Having achieved a good rapport and the trust of the patient, this doctor heard the following narrative: the patient was fully convinced that she had leprosy, even in the face of the negative biopsies. She knew, from information received in health clinics, what the main symptoms of leprosy are. She told that although the test results were negative, she was sure that she had been infected by this illness and that some of her symptoms, mainly those of her nose, mouth and skin, were evidence of her leprosy. The patient also complained of 'a smell of leprosy'. The doctor asked her about the occasion on which she was contaminated and she answered that she has a neighbor who developed the disease. She then hesitantly confessed that this neighbor once kissed her against her will; after that, she discovered that he had developed the disease and he was being treated.

The doctor convinced her that she needed a different approach for her condition and she was referred to a psychologist in the Psychosomatic Unit. She came for this consultation with her husband. At the beginning, she insisted on her physical condition, focusing exclusively on her body symptoms, and showed her nose, mouth and the skin of her arms. She had lost the hair on her arms and the skin was very thin and dry. Slowly the interview moved to her psychological life. When more complex issues of her emotional life emerged, her husband was asked to leave the room and wait outside.

She described herself as a religious woman, regularly taking part in services at her church, a Christian evangelical denomination called 'The Jehovah's Witnesses'. She and her husband, and several of their neighbors, have the same faith. One of them, according to her, fell in love with her and pursued her. On one occasion, he forcibly kissed her, and since then, she had avoided him. When she found out that he was sick, having contracted leprosy, she believed that she had been contaminated by him. The patient denied she needed psychotherapy, focusing on the physical origin of her symptoms.

Between the sessions, she was seen by a psychiatrist. Her complaints were the same and the doctor made a diagnostic hypothesis of conversion disorder, and considered the patient very uncooperative. She was using a facemask, covering her nose and mouth and declared that she had leprosy. She accused the doctors of misconduct because they were unable to 'confirm' her disease. Her husband agreed with her complaints and supported her. Both denied that she suffered from any mental problems. The psychiatrist felt frustrated because the patient did not allow a thorough examination and insisted on showing the parts of her body where she perceived changes. She did not accept to return for further interviews.

The psychologist and her general clinician decided to try a placebo strategy, since she always insisted that she wanted specific treatment for her putative disease, that is, she demanded to be treated for her leprosy, although her doctors had tried to convince her that she definitely was not infected. The physician prepared some innocuous pills and assured her that they were efficient against her disease. She did not make a return visit to the physician, but admitted to the psychologist that she did not believe that she had been prescribed 'real' medications for leprosy, and that, in her opinion, she had received 'calming pills' (anxiolytic drugs). She showed mistrust and insisted that she was certain that she had the 'terrible' disease, even though it had not been diagnosed. Probabyly the doctors were incapable of curing her, she declared in a depressive tone.

She was invited to return for more sessions, to follow psychodynamic psychotherapy in a weekly sequence, but she alleged difficulties due to the distance from her hometown (40 km away) and her weakness and difficulties to walk. 
This was clear resistance on her part, and she did not agree to explore all the possible connections between her beliefs and moral conflicts related to the appearance of her symptoms. Then, the psychologist insisted that she should look for psychotherapeutic care in her hometown.

After one month (31/7/14), she returned for a consultation in the Dermatology Department. Her complaints were loss of $20 \mathrm{~kg}$ in the previous two years, pain in her limbs, excessive sensitivity to heat and cold, pain in her palate and a feeling of a fistula between her mouth and her nose.

The skin biopsy found no abnormalities. The diagnosis was superficial and unspecific perivascular dermatitis. She was discharged with a prescription of mild palliative drugs for her superficial wounds.

Eight months later (3/3/15), she returned complaining of worsening pain, in particular the painful lesions in her mouth and nose, and weakness, with difficulties to swallow and to feed herself. She declared that she did not want psychological or psychiatric help, due to her poor physical condition and to her belief in a putative 'hidden' leprosy.

Another physical examination was performed with electroneuromyography (10/4/15) to investigate changes in peripheral sensory and motor nerves characteristic of leprosy, but no abnormalities were found.

Then, a large medical council discussed her case. Doctors from different specialties and the psychologist presented their views. The conclusion was that there was no evidenced organic disease. Her weakness was attributed to a poor, almost anorexic diet; the symptoms of her mouth and throat were due to mild stomatitis, and the thinness and sensitivity of the skin on her nose were probably caused by excessive cleaning, that is, a possible factitious condition.

The patient and her husband were waiting outside the meeting and they were invited to enter. The lead physician explained to the couple, in simple but detailed phrases, that the doctors in this meeting were sure that she did not have leprosy. He explained that her vague symptoms could be treated with creams and vitamins. In conclusion, he stressed the need for her to seek psychological help in order to improve her health and regain her quality of life.

She accepted to go again to see the psychologist, and again she arrived with her husband. After a brief consultation with the two together, the interview continued with just her. Again, she focused on the intensity of her physical suffering and she expanded on her complains: her skin was very thin and sensitive, and merely touching it hurt her. Every part of her body was painful, and the sensitivity in her nose and her vagina was unbearable. Sex was impossible for her. Her husband, fortunately in her view, agreed that she was suffering excessively and that she could not perform any domestic (or 'marital') duties.

Slowly she described in detail her hygiene rituals, and it was clear that she used many products (cotton swabs and different medicines and soaps) to clean her nose and body. This was probably the reason for the constant inflammations of her nose. Although she admitted that she excessively cleaned her body, using too many products, she did not believe that she might be causing her symptoms (factitious behavior).

The psychological treatment continued the following weeks when the question of her putative leprosy was discussed. She told that she could not understand why the man who allegedly infected her was cured of his leprosy, while she still had the disease. She clearly held the belief, against all medical evidence, that she had leprosy. Nevertheless, at the same time, she showed signs of dissociation. She did not admit to having feelings of guilt, although she had already confessed (to her general clinician), that 'there had been more than just one single kiss'. She considered her neighbor guilty and the one who deserved to be punished; but he was free of punishment.

She also said that she could not discuss this subject with her 'shepherd', the priest of her church, although he knew, in general terms, about the diseases of both her and her neighbor. On investigating whether she knew about the biblical references to leprosy, she admitted that she was very well informed about several passages where this disease is mentioned in the Bible.

It is very important to stress here that the Old Testament is very different to the New Testament in this respect. Jesus Christ came to give forgiveness, to show mercy for our sins. However, Jehovah, God in the Old Testament, is much more severe and punitive. It is enough to remember the punishment of Sodom and Gomorrah, and to learn that in her denomination the punishment for sins is always more certain and sometimes lethal.

There was still another complication, hidden deeply in her emotional life. She perceived that this man, her neighbor, was much older than she was, and reminded her of her father. Possibly this was the trigger for her unconscious decision to 'get sick of leprosy' as she was incapable of admitting her attraction for an old man, and her unconscious consent to be kissed: she had to face punishment, a divine punishment for an adulterous act, even 'against her will'. Moreover, if 
this punishment is at the same site as the crime, that is, the mouth, it will be more effective. The nose achieves its full importance, as it is one of the parts of the body most affected in lepers. Once she declared to the psychologist that she feared her nose would drop off. This would be a kind of 'public demonstration' of her 'sins'.

However, all these suppositions and her complex feelings of guilt and grief could not be worked out, as she left the treatment after the session in which she mentioned the biblical references to this disease. The continuation of her treatment could probably have helped her to understand how her body was carrying out her unconscious desire of being punished for having forbidden sexual desires. Contradictory beliefs of moral and religious content mixed with guilt and anger composed her symptoms. Her husband came one final time to a consultation and was instructed to help his wife to continue treatment, and to try to stop supporting the belief that she really had leprosy.

\section{CONCLUSION}

This study shows the complexities involved in the treatment of pain conditions. Pain is connected to many different sources, such as with biological, psychological, cultural and social origins. It should be investigated and treated by a multidisciplinary team in order to have a wider and more efficient approach.

\section{ETHICS APPROVAL AND CONSENT TO PARTICIPATE}

The study received Ethical approval by the Ethics Committee of the State Medical College of Sao Jose do Rio Preto, Brazil, number 5447/2010.

\section{HUMAN AND ANIMAL RIGHTS}

No animals were used in this research. All research procedures followed were in accordance with the ethical standards of the committee responsible for human experimentation (institutional and national), and with the Helsinki Declaration of 1975, as revised in 2008 (http://www.wma.net/en/20activities/10ethics/10helsinki/).

\section{CONSENT FOR PUBLICATION}

Not applicable.

\section{CONFLICT OF INTEREST}

The author confirms that this article content has no conflict of interest.

\section{ACKNOWLEDGEMENTS}

Author Lazslo Antonio Ávila wrote the paper and coordinated the general draft. Drs. Eurides M. O. Pozetti, Rosa M. Soubhia and Andreia Tomiyasu described and revised the dermatological issues of the paper. Dr. Gislaine F. Fares described the general clinics conducts. Dr. Marilia C. Oliveira described the psychiatric aspects of the case. All authors discussed the results and approved the final text.

\section{REFERENCES}

[1] Recommended by the IASP Subcommittee on Taxonomy. Pain terms: a list with definitions and notes on usage. Pain 1979 ; $6(3)$ : 249. [PMID: 460932]

[2] McCaffery M. Nursing Practice Theories Related to Cognition, Bodily Pain, and Man-Environment Interactions. Los Angeles: University of California 1968.

[3] Radat F, Margot-Duclot A, Attal N. Psychiatric co-morbidities in patients with chronic peripheral neuropathic pain: a multicentre cohort study. Eur J Pain 2013; 17(10): 1547-57. [PMID: 23720357]

[4] Lewandowski Holley A, Law EF, Zhou C, Murphy L, Clarke G, Palermo TM. Reciprocal longitudinal associations between pain and depressive symptoms in adolescents. Eur J Pain 2013; 17(7): 1058-67.

[http://dx.doi.org/10.1002/j.1532-2149.2012.00272.x] [PMID: 23280775]

[5] Wojakiewicz A, Januel D, Braha S, Prkachin K, Danziger N, Bouhassira D. Alteration of pain recognition in schizophrenia. Eur J Pain 2013; 17(9): 1385-92.

[http://dx.doi.org/10.1002/j.1532-2149.2013.00310.x] [PMID: 23529960]

[6] Clark MR. Psychiatric issues in chronic pain. Curr Psychiatry Rep 2009; 11(3): 243-50.

[http://dx.doi.org/10.1007/s11920-009-0037-6] [PMID: 19470287] 
[7] Borsook D, Becerra L, Carlezon WA Jr, et al. Reward-aversion circuitry in analgesia and pain: implications for psychiatric disorders. Eur J Pain 2007; 11(1): 7-20. [http://dx.doi.org/10.1016/j.ejpain.2005.12.005] [PMID: 16495096]

[8] Marazziti D, Mungai F, Vivarelli L, Presta S, Dell’Osso B. Pain and psychiatry: a critical analysis and pharmacological review. Clin Pract Epidemol Ment Health 2006; 2: 31. [http://dx.doi.org/10.1186/1745-0179-2-31] [PMID: 17087832]

[9] Jussila L, Paananen M, Näyhä S, et al. Psychosocial and lifestyle correlates of musculoskeletal pain patterns in adolescence: a 2-year followup study. Eur J Pain 2014; 18(1): 139-46.

[http://dx.doi.org/10.1002/j.1532-2149.2013.00353.x] [PMID: 23853106]

[10] Gereau RW IV, Sluka KA, Maixner W, et al. A pain research agenda for the 21st century. J Pain 2014; 15 (12): 1203-14. [http://dx.doi.org/10.1016/j.jpain.2014.09.004] [PMID: 25419990]

[11] Ferreira-Valente MA, Pais-Ribeiro JL, Jensen MP. Associations between psychosocial factors and pain intensity, physical functioning, and psychological functioning in patients with chronic pain: a cross-cultural comparison. Clin J Pain 2014; 30(8): $713-23$. [http://dx.doi.org/10.1097/AJP.0000000000000027] [PMID: 24042349]

[12] Campbell P, Bishop A, Dunn KM, Main CJ, Thomas E, Foster NE. Conceptual overlap of psychological constructs in low back pain. Pain 2013; 154(9): 1783-91. [http://dx.doi.org/10.1016/j.pain.2013.05.035] [PMID: 23726935]

[13] Wegener ST, Castillo RC, Haythornthwaite J, Mackenzie EJ, Bosse MJ. Psychological distress mediates the effect of pain on function. Pain $2011 ; 152(6): 1349-57$.

[http://dx.doi.org/10.1016/j.pain.2011.02.020] [PMID: 21396777]

[14] olde Hartman TC, Borghuis MS, Lucassen PL, van de Laar FA, Speckens AE, van Weel C. Medically unexplained symptoms, somatisation disorder and hypochondriasis: course and prognosis. A systematic review. J Psychosom Res 2009; 66(5): 363-77. [http://dx.doi.org/10.1016/j.jpsychores.2008.09.018] [PMID: 19379952]

[15] Fillingim RB. Individual differences in pain responses. Curr Rheumatol Rep 2005; 7(5): 342-7. [http://dx.doi.org/10.1007/s11926-005-0018-7] [PMID: 16174481]

[16] Suvinen TI, Reade PC, Kemppainen P, Könönen M, Dworkin SF. Review of aetiological concepts of temporomandibular pain disorders: towards a biopsychosocial model for integration of physical disorder factors with psychological and psychosocial illness impact factors. Eur $\mathrm{J}$ Pain 2005; 9(6): 613-33.

[http://dx.doi.org/10.1016/j.ejpain.2005.01.012] [PMID: 15978854]

[17] Ciaramella A, Grosso S, Poli P, et al. When pain is not fully explained by organic lesion: a psychiatric perspective on chronic pain patients. Eur J Pain 2004; 8(1): 13-22. [http://dx.doi.org/10.1016/S1090-3801(03)00062-4] [PMID: 14690670]

[18] McWilliams LA, Cox BJ, Enns MW. Mood and anxiety disorders associated with chronic pain: an examination in a nationally representative sample. Pain 2003; 106(1-2): 127-33.

[http://dx.doi.org/10.1016/S0304-3959(03)00301-4] [PMID: 14581119]

[19] Loeser JD, Melzack R. Pain: an overview. Lancet 1999; 353(9164): 1607-9. [http://dx.doi.org/10.1016/S0140-6736(99)01311-2] [PMID: 10334273]

[20] Merskey H, Lau CL, Russell ES, et al. Screening for psychiatric morbidity. The pattern of psychological illness and premorbid characteristics in four chronic pain populations. Pain 1987; 30(2): 141-57.

[http://dx.doi.org/10.1016/0304-3959(87)91070-0] [PMID: 3670866]

[21] Bonica JJ. The need of a taxonomy. Pain 1979; 6(3): 247-8. [http://dx.doi.org/10.1016/0304-3959(79)90046-0] [PMID: 460931]

[22] Köteles F, Simor P. Modern health worries, somatosensory amplification, health anxiety and well-being. Eur J Ment Health 2014 ; 9: $20-33$. [http://dx.doi.org/10.5708/EJMH.9.2014.1.2]

[23] Nakao M, Barsky AJ. Clinical application of somatosensory amplification in psychosomatic medicine. Biopsychosoc Med 2007; 1: 17. [http://dx.doi.org/10.1186/1751-0759-1-17] [PMID: 17925010]

[24] Barsky AJ, Goodson JD, Lane RS, Cleary PD. The amplification of somatic symptoms. Psychosom Med 1988; 50(5): 510-9. [http://dx.doi.org/10.1097/00006842-198809000-00007] [PMID: 3186894]

[25] Romano JM, Molton IR, Alschuler KN, Jensen MP, Schmaling KB, Buchwald DS. Reported Pain and Fatigue Behaviors Mediate the Relationship Between Catastrophizing and Perceptions of Solicitousness in Patients With Chronic Fatigue. J Pain 2016; 17(3): 328-35. [http://dx.doi.org/10.1016/j.jpain.2015.10.020] [PMID: 26646398]

[26] Turner J, Sherman K, Anderson M, Balderson B, Cook A, Cherkin D. Catastrophizing, pain self-efficacy, mindfulness, and acceptance: relationships and changes among individuals receiving CBT, MBSR, or usual care for chronic back pain. J Pain 2015 ; 16 : S 96.

[27] Gillanders DT, Ferreira NB, Bose S, Esrich T. The relationship between acceptance, catastrophizing and illness representations in chronic pain. Eur J Pain 2013; 17(6): 893-902. [http://dx.doi.org/10.1002/j.1532-2149.2012.00248.x] [PMID: 23169693] 
[28] Velly AM, Look JO, Carlson C, et al. The effect of catastrophizing and depression on chronic pain--a prospective cohort study of temporomandibular muscle and joint pain disorders. Pain 2011; 152(10): 2377-83. [http://dx.doi.org/10.1016/j.pain.2011.07.004] [PMID: 21871734]

[29] Wade JB, Riddle DL, Price DD, Dumenci L. Role of pain catastrophizing during pain processing in a cohort of patients with chronic and severe arthritic knee pain. Pain 2011; 152(2): 314-9. [http://dx.doi.org/10.1016/j.pain.2010.10.034] [PMID: 21130571]

[30] Keefe FJ, Lefebvre JC. Catastrophizing research: Avoiding conceptual errors and maintaining a balanced perspective. Pain Forum. 8: 176-80.

(C) 2017 Avila et al.

This is an open access article distributed under the terms of the Creative Commons Attribution 4.0 International Public License (CC-BY 4.0), a copy of which is available at: (https:/creativecommons.org/licenses/by/4.0/legalcode). This license permits unrestricted use, distribution, and reproduction in any medium, provided the original author and source are credited. 